\title{
Screening of patients with non-alcoholic fatty liver disease using non-invasive methods in clinical practice
}

\author{
Internal Clinic for Liver Disease Diagnosis and Treatment, Remedium s.r.o. \\ St. Elizabeth University of Health and Social Sciences, Bratislava \\ Slovak Society of Practical Obesitology, Bardejov
}

mriab9@gmail.com

\author{
Беловічкова М. \\ Скринінг пацієнтів 3 неалкогольною жировою \\ хворобою печінки з використанням неінвазивних \\ методів в клінічній практиці \\ Клініка діагностики хвороб печінки і лікування \\ Санкт-Елізабет університет охорони здоров'я \\ та суспільних наук, Братислава \\ Словацьке товариство практичної обезітології, Бардейов
}

Беловичкова М.

Скрининг пациентов с неалкогольной жировой болезнью печени с использованием неинвазивных методов в клинической практике

Клиника диагностики болезней печени и лечения

Санкт-Элизабет университет здравоохранения и общественных наук, Братислава

Словацкое общество практической обезитологии, Бардейов

\section{Introduction}

NAFLD - Non-alcoholic fatty liver disease - is characterized by the presence of hepatic steatosis - by excess accumulation of fat in liver tissue (steatosis must be present in more than 5\% of hepatocytes), which is associated with insulin resistance (IR). NAFLD is considered benign, non-progressive form of the disease, while NASH - Non-alcoholic steatohepatitis - is a progressive form with the development of fibrogenesis, with high risk for liver cirrhosis and hepatocellular carcinoma of the liver [1,2].

NAFLD is the most common liver disease in economically developed countries. Over the past 20 years, the incidence of NAFLD has doubled worldwide, while the number of other chronic liver diseases has remained without significant changes.

The prevalence of NAFLD ranges between $17-46 \%$ depending on the diagnostic procedures, ethnicity, age, gender [3].

For the future, we have to face not only the increase of absolute number of affected patients, but more important fact is, that the number of patients with advanced liver fibrosis will increase. Fibrosis is the most important predictor of overall and hepatic mortality.

The prevalence of NAFLD increases with age because patients of higher age have more risk factors for metabolic syndrome. It is generally considered that the progression of NAFLD into steatohepatitis or into fibrosis results rather from the associated diseases and their duration than from the age itself. The risk factors for development of NAFLD include: obesity, type 2 diabetes mellitus (DM), hypertriglyceridaemia. However, NAFLD may be present in $7 \%$ of those who do not suffer from obesity. In this case, the accumulation of visceral fat must be present [4].
The aim of study: to find out the incidence of nonalcoholic fatty liver disease in the internal outpatient clinic during 2017-2018 and compare the degree of liver damage found through transient elastography and fibrosis indices.

\section{Materials and methods}

When an increased level of liver function tests is detected, general practitioners send patients from the Bardejov district and the wider surroundings to the Internal outpatient clinic focusing on the diagnosis and treatment of liver diseases in Bardejov Spa for the purpose of performing differential diagnosis of liver diseases. A total of 742 new patients were examined in the outpatient clinic in years 2017 and 2018.

We took the medical history of each new patient focusing also on their eating habits and abuses. Their blood pressure, pulse, height, weight are measured and then the BMI is calculated. Based on the medical history, we are trying to suspect whether a particular patient may suffer from a nonalcoholic, alcoholic or viral liver disease, or the drug-induced liver injury or autoimmune disease.

We collect a blood sample for differential diagnosis of liver disease from each new patients coming to the clinic for the first time. This collection includes: blood count with differential, blood clotting, immunoglobulins, wide biochemical screening (glycemia, creatinine, bilirubin, cholesterol, triglycerides, HDL and LDL cholesterol, albumin, sodium, potassium, CRP, liver tests: AST, ALT, ALP, GGT, thyroid hormones, oncomarkers (liver, colon, pancreas), milk allergy, gluten allergy, hepatitis B and hepatitis C (antibody determination) collection, determination of ceruloplasmin and copper levels (to exclude Wilson's disease), sampling for testing iron, iron binding capacity, ferritin (to exclude hemochromatosis), $\alpha$-1-antitrypsin, autoantibodies. 
In each new patient we perform a USG examination (an ultrasoundscan of the abdominal cavity), which includes an examination of: the liver with measurements of its dimensions, the width of the portal vein, and the determination of the blood flow through the vena portae, evaluation of its surface, homogeneity, structure, echogenicity, examination of cholecyst (gallbladder), pancreas, spleen, kidney, bladder.

When an enlarged liver, a fatty liver, liver with partially retained or erased structure, liver with a slowed flow through the portal vein are detected, a transient elastography examination is suggested to the patient. Transient elastography (TE) is a painless, non-invasive method that measures stiffness of the liver tissue (liver stiffness). It evaluates the speed of shock waves as they propagate through the liver. It is used to assess a degree of liver fibrosis (according to the Metavir classification), in chronic hepatitis B and C, chronic cholestatic diseases, alcoholic liver disease, nonalcoholic fatty liver disease, autoimmune hematitis. With high accuracy it manages to confirm or refute cirrhosis [5].

The results of previous clinical studies suggest that TE achieves a high degree of accuracy in detecting more advanced liver fibrosis $(\geq F 2)$. The cut-off level for identifying patients with significant fibrosis $(\mathrm{F} \geq 2)$ varies from 7.1 to $8.7 \mathrm{kPa}$ according to clinical studies results. The overall AUROC for diagnosis of cirrhosis is 0.952 , which far exceeds expectations of a method of similar type in human medicine [6].

With selected laboratory indicators we can conclude about the progression of liver disease (presence of fibrosis build up of scar tissue). They are used for quick orientation, whether the patient should be promptly sent to a specialist for examination. We introduce some of them:

AST/ALT ratio: Aminotransferases AST, ALT are the most commonly used enzymes that signal liver damage. They are the indicator of hepatocyte membrane permeability and liver cell integrity, and also they are the values used in most mathematical models investigating liver fibrosis.

APRI index: Since 2003, the APRI index has been one of the most commonly used and validated indices used for noninvasive diagnosis of liver fibrosis. The authors of the index identified AST activity, platelet count and their ratio as the most important predictors of fibrosis. The idea of APRI is that fibrosis progression and increase in portal pressure are associated with decreased thrombopoietin production ofhepatocytes, increased platelet sequestration in the spleen, and decreased AST degradation [7].

BARD score: It is used to assess the severity of liver fibrosis in NAFLD. It consists of 3 items: AST/ALT ratio $\geq 0.8$ ( 2 points), BMI $\geq 28 \mathrm{~kg} / \mathrm{m}^{2}$ (1 point), presence of diabetes 1 point. Possible score is 0 to 4 points. BARD score 0 or 1 have a high negative predictive value for advanced fibrosis $(96 \%)$ [8].

FIB-4 index: Fib-4 combines standard biochemical tests extended by platelet counts, serum ALT and AST activity and patient's age [9].

NAFLD fibrosis score: The NAFLD FS allows the quantification of steatosis with higher sensitivity compared to USG. It is calculated by an online calculator out of 6 parameters (age, BMI, IGF/diabetes, ALT, AST, platelet count, albumin). The NAFLD score detects fibrosis with $90 \%$ sensitivity and $97 \%$ specificity [10].

\section{Results}

Out of a total of 742 patients (new patients examined in our outpatient clinic in 2017 and 2018), we included 300 patients in our sample. We intended to focus on non-alcoholic fatty liver disease in overweight/obese patients and in patients with type 2 diabetes mellitus who appeared to be more at risk for liver damage.The average age of the patients in the group was 59 years, women accounted for $53.3 \%$ of the group (160), number of men was 140 . Obesity and severe obesity occurred in 203 members of the group (67.6\%). Type 2 diabetes mellitus was present in 191/300 (63.7\%).

To process the sample the following statistical processing methods were used: a) descpriptive statistics; b) correlation and regression analysis; c) testing the statistical significance of differences in samples with parametric data distribution using the t-test (e.g. for indicators and indexes that have a continuous normal distribution); d) testing the statistical significance of differences in samples with nonparametric data distribution using the Mann-Whitney test and the KruskalWallis test (ANOVA) (e.g. 5 categories of fibrosan, BMI categories - Kruskal-Wallis test used, for diabetes mellitus Mann-Whitney test); e) test validity analysis using the ROC method (receiver operating characteristics curve).

The aim of the statistical analysis of the group was to find out the mutual correlations of the monitored parameters, indexes of liver damage and degree of liver damage (using fibroscan), the influence of the presence of diabetes mellitus on the degree of liver damage.

Analysis of mentioned dependencies (correlations) or of the statistical significance of the differences in the samples was divided into 10 working hypotheses:

H1: the degree of liver damage indicated by fibroscan correlates with values of fibrosis indices AST/ALT, FIB-4, BARD, NAFLD FS

H1 was confirmed. There is a statistically significant correlation between Fibroscan and fibrosis indices in all 4 monitored indices. The best found correlation was between Fibroscan and NAFLD FS.

H2: the degree of liver damage will be higher in patients with obesity

$\mathrm{H} 2$ was confirmed. There is a statistically significant correlation between the degree of liver damage and obesity $(\mathrm{p}=0.001$, Pearson coef. $=0.272)$.

H3: the degree of liver damage (fibrosis) is higher in patients with DM than in patients without DM

H3 was confirmed. In patients with DM, from Fibroscan examination results, the degree of liver damage (fibrosis) is statistically significantly higher $(\mathrm{F}=0.001)$.

H4: there is a significant correlation between the degree of damage (fibrosis) and the laboratory indicators AST, ALT, GMT, ALP, TC, TAG, HDL, LDL

$\mathrm{H} 4$ on the correlation of laboratory parameters with the degree of liver damage was confirmed in laboratory indicators: AST, GMT, TC and LDL. It was not confirmed for the indicators: ALT, ALP, TAG and HDL. 
H5: there is a significant correlation between the level of obesity and the laboratory indicators AST, ALT, GMT, ALP, TC, TAG, HDL, LDL

H5 was confirmed in only one indicator - TAG (Pearson $=-0.121, \mathrm{p}=0.038)$. For other indicators, the correlation with the degree of damage was not confirmed.

H6: in the presence of DM the incidence of obesity will be higher than in its absence

H6 was not confirmed. The differences in the frequency of obesity among patients depending on the presence of DM are not statistically significant $(\mathrm{p}=0.202)$.

H7: the values of laboratory indicators and liver damage indices will be significantly different in the presence of DM

H7 was confirmed for the indicators ALP, TC, TAG,

LDL and BARD, FIB-4 and NAFLD, and was not confirmed for the indicators AST, ALT, GMT and HDL and AST/ ALT index.

H8: laboratory indicators will be significantly different according to gender

H8 on the significance of differences in laboratory values according to gender was confirmed for all laboratory parameters except for the TAG $(p=0.954)$.
H9: the values of liver damage indices and liver damage degree significantly increase with patients age

H9 was confirmed for the degree of damage as detected by Fibroscan as well as for the damage indices, except for the BARD index. The degree of damage detected by Fibroscan significantly illustrates the increase in the number of patients with the degree of damage 2,3 and $4(10.1 \%, 13.1 \%$ and $24.2 \%$ ), compared to a frequency of $1-2.7 \%$ at the age of patients under 50 years.

H10: number of patients with DM is significantly higher in elderly patients

H10 was confirmed. The number of patients diagnosed with DM significantly increases with the age of patients $(p=0.001)$.

Results obtained by univariate analysis (UVA) in testing dependency (correlation) or significant differences in variables and the degree of Fibroscan-derived damage, TAG and NAFLD damage index, in which statistical significance was observed in UVA, were analyzed using multivariate analysis (MVA) from independent variables BMI, age and gender as covariates. The results are summarized in Table.

Table. Results from multivariate analysis

\begin{tabular}{|c|c|c|c|c|}
\hline \multirow{2}{*}{ Variables } & \multirow{2}{*}{ Categories } & \multicolumn{3}{|c|}{ p-value } \\
\hline & & Fibroscan & TAG & NAFLD \\
\hline BMI dichotomous & $\begin{array}{l}<=25 \\
>25\end{array}$ & 0,012 & 0,041 & 0,001 \\
\hline Age & $\begin{array}{c}<=50 \mathrm{yr} . \\
>50 \mathrm{yr} .\end{array}$ & 0,001 & 0,001 & 0,001 \\
\hline Gender & Malefemale & 0,227 & 0,379 & 0,453 \\
\hline BMI \& age dichotomous & $\begin{array}{l}<>B M I=25 \\
<>\text { age } 50 \mathrm{yr} .\end{array}$ & 0,034 & 0,022 & 0,036 \\
\hline BMI \& age dichotomous \& DM & $\begin{array}{c}<>\text { BMI } 25 \\
<>\text { age } 50 \mathrm{yr} \text {. } \\
\text { DM } 0,1\end{array}$ & 0,012 & 0,021 & 0,048 \\
\hline
\end{tabular}

Conclusions from multivariate analysis: the results of the MVA confirm the conclusions of the univariate analysis and can be summarized as follows:

1. Independent predictors of liver damage are obesity, DM and patient's age

2. Independent predictors of DM is obesity and age of patients $(\mathrm{p}=0.001)$.

3. Gender, as expected, does not appear to be a predictive factor.

For the final evaluation of validity of the tests used in determination of liver damage, we used a common method a so called „ROC analysis“ (received operating curve). Results are shown in graphs 1 and 2 .

Graph 2 clearly shows, that the NAFLD and Fibroscan tests have the highest sensitivity. Tests drawn near the diagonal, have low and insufficient sensitivity.

\section{Discussion}

In the last 30 years due to the epidemic of obesity and metabolic syndrome, NASH has become serious health problem. Our results of the multivariant analysis confirm the conclusions of the univariate analysis and can be summarized as follows:

1. Independent predictors of liver damage in NAFLD patients are obesity, DM and patient's age.

2. Independent predictors of DM is obesity and age of patients $(\mathrm{p}=0.001)$.

It is supposed that NAFLD, mainly associated with type $2 \mathrm{DM}$ and the metabolic syndrome, is the most common chronic disease worldwide affecting $15-40 \%$ of the world population [11]. 


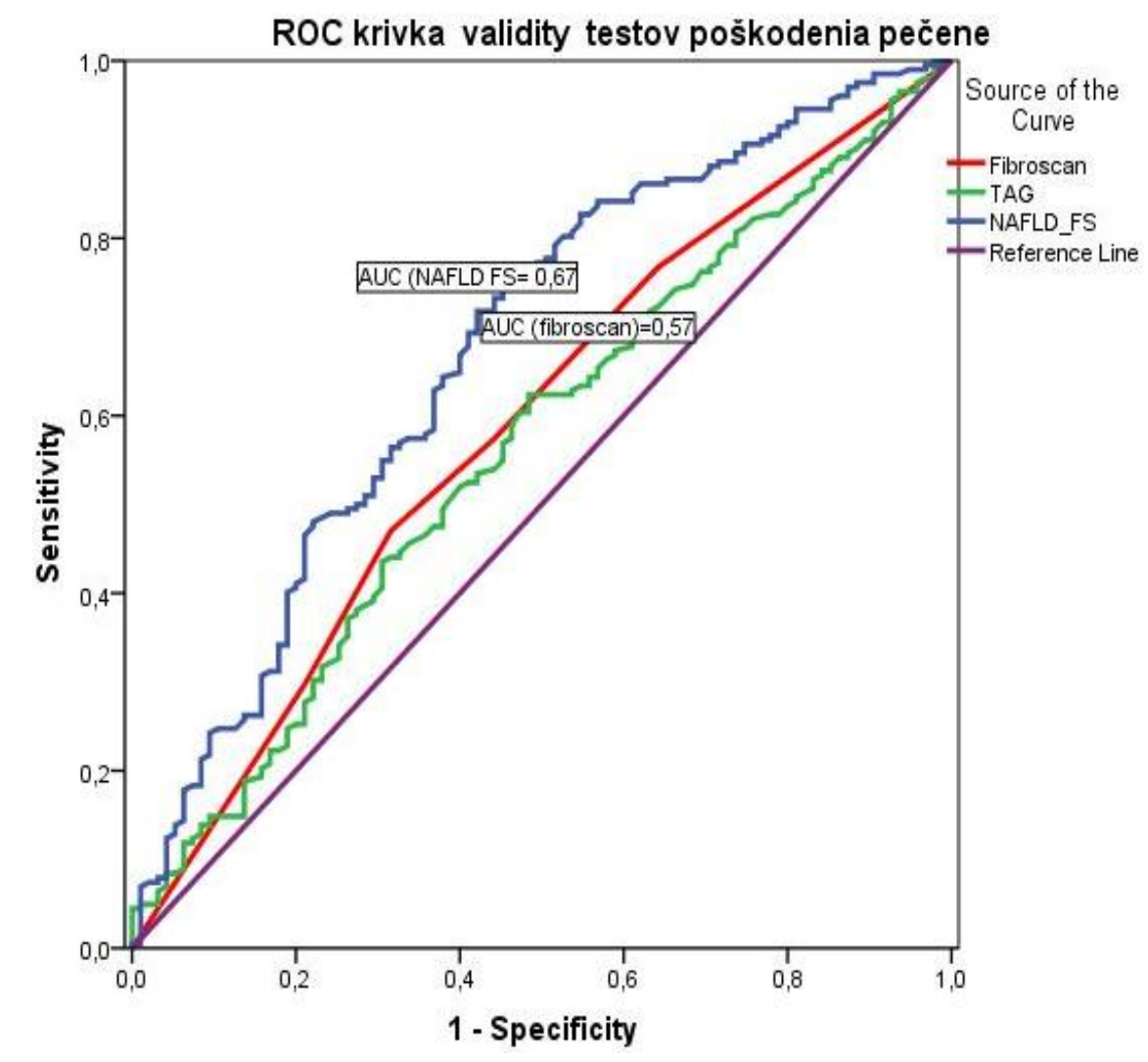

Graph 1. Graphical representation of ROC curves for TAG, NAFLD and Fibroscan, which showed the highest sensitivity in both, UVA and MVA (ROC curves were determined for ref. value BMI $=25$ )

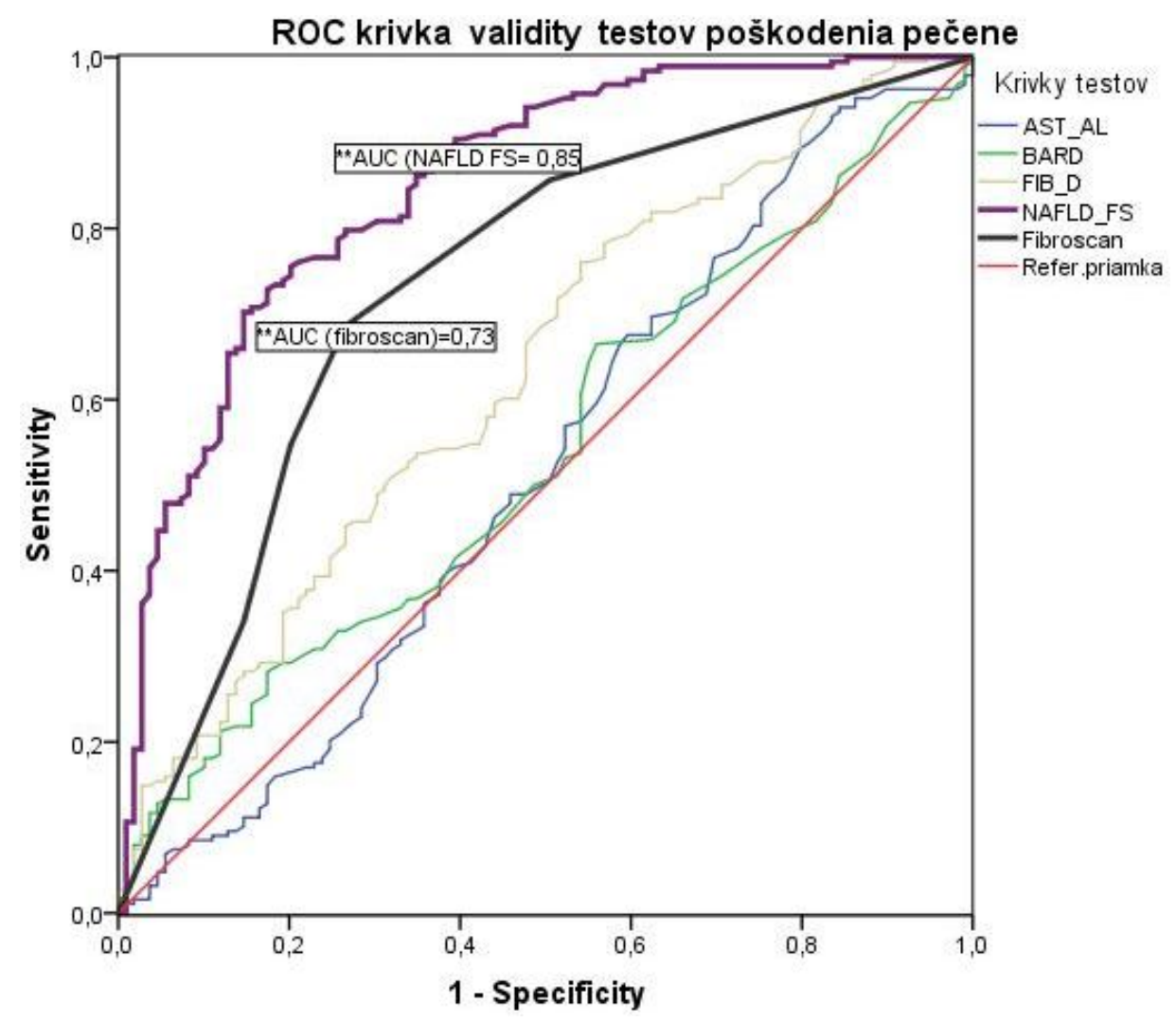

Graph 2. Representation of ROC curves for the age group over 50 years and fibroscan tests and damage indices 
Epidemiological studies have shown that patients with NAFLD have higher total mortality than the general population has. It is not only affected by cirrhosis, but especially by cardiovascular diseases and extrahepatic malignancies (colon and breast carcinoma) [12,13]. Therefore, active screening for cardiovascular diseases in patients with NAFLD, independent of the presence of risk factors, is needed. Therefore, in patients with diagnosed metabolic syndrome it is necessary to specifically look for liver disease at the same extent as is now being looked for the other complications of diabetes $[14,15]$.

The results of statistical analysis of individual fibrosis indexes in a group of patients examined and treated in the Internal outpatient clinic focusing on the diagnosis and treatment of liver diseases in Bardejov Spa confirmed the validity of laboratory tests in assessing liver damage as well as their easy applicability for clinical practice. However, a comprehensive assessment of a patient using the fibrosis index, abdominal cavity ultrasound examination and transient elastography examination is ideal.

\section{Conclusions}

The disease NAFLD/NASH is considered to be the organ/hepatic manifestation of metabolic syndrome, and probably plays a key role in the pathogenesis of systemic atherosclerosis [16,17].

Due to the pandemic extent of NAFLD, liver biopsy cannot be performed in all the patients suspected with this disease. Therefore, the most effective non-invasive laboratory methods such as fibrosis indexes and methods using elastometric devices (out of which the most widely used is transient elastography), are being used, but are also still being searched for so to be used in routine practice.

\section{References}

1. Belovičová M.: Non-Alcoholic fatty liver disease and its impact on public health. Krakow: Towarzystwo Slowakow w Polsce. 2019. 95 pp.

2. Bellentani S., Scaglioni F., Marino M., Bedogni G 2010: Epidemiology of non-alcoholic fatty liver disease. Dig Dis. 2010; 28: 155161.

3. Castera, L. et al.: Early detection in routine clinical practice of cirrhosis and oesophageal varices in chronic hepatitis C: comparison of transient elastography (FibroScan) with standard laboratory tests and non-invasive scores. Journal of Hepatology 2009; 50: 59-68.

4. Koller,T. NAFLD Summit 2018. Trends in hepatology 2018; 10(2): 4-7.

5. Belovičová, M.: Selected liver diseases. Textbook for medical students. 1. ed., Bardejov: SSPO, 2018, 111p.

6. Belovičová, M., Fedorková, I., Balážová, I.: Transient elastography - screening method for diagnosis of nonalcoholic fatty liver disease in obese patiens. Social Health Spectrum 1.02.2017.

7. Kruger, FC., Daniels, CR., Kidd, M., Swart, G., Brundyn, K., Rensburg, KV., Kotze, M.: APRI: A simple bedside marker for advanced fibrosis that can avoid liver biopsy in patients with NAFLD/NASH. S Afr Med J. 2011; 101: 477-80.

8. Castera, L., Yuen Chan, HL., Arrese, M. et al.: Clinical Practice Guidelines: Non-invasive tests for evaluation of liver disease severity and prognosis. Journal of Hepatology 2015; 63: $237-264$.

9. Koula, M., Hrúzová, M., Harmáček, D. et al.: Methods of non-invasive determination of liver fibrosis. Gastroent Hepatol 2016; 70(2): 118-124.

10. Angulo, P., Hui, JM., Marchesini, G. et al.: The NAFLD fibrosis score: a noninvasive system that identifies liver fibrosis in patients with NAFLD. Hepatology. 2012; 45:846-54.

11. Belovičová, M., Mašterová, V.:Non-alcoholic fatty liver disease - severe comorbidity of diabetes. Forum Diab 2016 ; 5(1): 45-48.

12. Brúha, R., Dvořák, K., Petrtýl, J.: Liver disease in diabetics. Internal Medicine 2013; 59(7): 546-550. $365-367$.

13. Brúha, R.:Hepatic impairment screening in patients with type 2 diabetes mellitus Gastroent hepatol 2015; 69(4):

14. Popovičová, M. - Kovácsová, B. 2016. Importance of fasting and postprandial glycemia in prevention of diabetic retinopathy. In Florence. Prague: Ambit Media, a. s., ISSN 1801-464X, 2016, vol. 7, no. 11., p. 18-22.

15. Barkasi, D. 2018. Diabetic in the process of education. In: DIAspectrum. ISSN: 1337-592X, 2018, vol. VII., No. $1 / 2018$, p. $12-13$.

16. Koller, T. Current trends in laboratory diagnosis of liver diseases at EASL 2019. Trends in hepatology 2019; 11(1): 6-7.

17. Zima, M. Non-alcoholic fatty liver disease. Viapract., 2008, 5 (4/5): 166-169.

Дата надходження рукопису до редакції: 10.10.2019 р.

The aim of study: to find out the incidence of non-alcoholic fatty liver disease in the internal outpatient clinic during 20172018 and compare the degree of liver damage found through transient elastography and fibrosis indices.

Materials and methods. A total of 742 new patients were examined in the outpatient clinic. In each new patient we performed blood sample examination and a USG examination. When an enlarged liver or fatty liver was detected, a transient elastography was done. We included 300 patients in our sample. Besides that we used selected liver fibrosis indices for detection of liver fibrosis and 
compared the results with fibroscan. We realized statistical analysis of results. The aim of the statistical analysis was to find out the mutual correlations of the monitored parameters, indices of liver damage and degree of liver damage (using fibroscan), the influence of the presence of diabetes mellitus on the degree of liver damage.

Results. The results of the multivariant analysis confirm the conclusions of the univariate analysis and can be summarized as follows: a) Independent predictors of liver damage are obesity, DM and patient's age; b) Independent predictors of DM is obesity and age of patients $(\mathrm{p}=0.001)$; $)$ Gender, as expected, does not appear to be a predictive factor.

Conclusions. The results of statistical analysis of liver fibrosis indices in a group of patients confirmed the validity of laboratory tests in assessing liver damage as well as their easy applicability for clinical practice. However, a comprehensive assessment of a patient using the fibrosis index, abdominal cavity ultrasound examination and transient elastography examination is ideal.

Key words: NAFLD - Non-Alcoholic fatty liver disease, NASH - Non-alcoholic steatohepatitis, obesity, diabetes mellitus, transient elastography, ultrasonography, liver fibrosis indices.

Мета дослідження: 3’ясувати захворюваність на неалкогольну жирову хворобу печінки в амбулаторній клініці внутрішніх хвороб протягом 2017-2018 років і порівняти ступінь пошкодження печінки, виявлений за допомогою транзиторної еластографії та показники фіброзу.

Матеріали та методи. В амбулаторній клініці було оглянуто 742 нових пацієнтів. Для кожного нового пацієнтами проводили експертизу зразків крові та експертизу ЗГС. При виявленні збільшеної печінки або жирної печінки була проведена транзиторна еластографія. Ми включили 300 пацієнтів у наше дослідження. Крім того, ми використовували вибрані показники фіброзу печінки для виявлення фіброзу печінки і порівнювали результати з фіброскануванням. Ми розуміли статистичний аналіз результатів. Метою статистичного аналізу було з'ясувати взаємні кореляції контрольованих параметрів, показники ураження печінки і ступінь ураження печінки (за допомогою фібросканування), вплив наявності цукрового діабету на ступінь ураження печінки.

Результати. Результати мультиваріантного аналізу підтверджують висновки одноваріантного аналізу і можуть бути узагальнені наступним чином: а) незалежні предиктори ураження печінки є: ожиріння, DM і вік пацієнта; б) незалежні предиктори DM - це ожиріння і вік пацієнтів ( $=0,001)$; в) стать, як і очікувалося, не є прогностичним фактором.

Висновки. Результати статистичного аналізу показників фіброзу печінки у групі пацієнтів підтвердили дійсність лабораторних аналізів при оцінці пошкоджень печінки, а також їх легку застосовність для клінічної практики. Однак, ідеально підходить комплексна оцінка пацієнта з використанням індексу фіброзу, УЗД органів черевної порожнини та транзиторна еластографія.

Ключові слова: неалкогольна жирова хвороба печінки, неалкогольний стеатогепатит, ожиріння, цукровий діабет, транзиторна еластографія, УЗД, показники фіброзу печінки.

Цель исследования: определить заболеваемость неалкогольной жировой болезнью печени в амбулаторной клинике внутренних болезней на пртяжении 2017-2018 годов и сравнить степень поражения печени, выявленную при помощи транзиторной эластографии и показатели фиброза.

Материалы и методы. В амбулаторной клинике было осмотрено 742 новых пациентов. Для каждого нового пациента проводили экспертизу образцов крови и экспертизу ЗГС. При выявлении увеличенной пеечени или жирной печени была проведена транзиторная эластография. Мы включили 300 пациентов в наше исследование. Кроме того, мы использовали избранные показатели фиброза печени для выявления фиброза печени и сравнили результаты с фибросканированием. Мы оценили статистический анализ результатов. Целью статистического анализа было выяснить взаимные корреляции контролируемых параметров, показатели поражения печени и степень поражения печент (при помощи фибросканирования), влияние присутствия сахарного диабета на степень поражения печени.

Результаты. Результаты мультивариантного анализа подтверждают выводы одновариантного анализа и могут быть обобщены следующим образом: а) независимыми предикторами поражения печени являются: ожирение, DM и возраст пациента; б) независимые предикторы DM - это ожирение и возраст пациентов $(\mathrm{p}=0,001)$; в) пол, как и ожидалось, не является прогностическим фактором.

Выводы. Результаты статистического анализа показателей фиброза печени в группе пациентов подтвердили правильность лабораторных анализов при оценке повреждений печени, а такжеих легкое применение в клинической практике. Однако, идеально подходит комплексная оценка пациента с ипользованием индекса фиброза, УЗИ органов брюшной полости и транзиторная эластография.

Ключевые слова: неалкогольная жировая болезнь печени, неалкогольный стеатогепатит, ожирение, сахарный диабет, транзиторная эластография, УЗИ, показатели фиброза печени.

\section{Відомості про автора}

Belovičová Mária - assoc. Prof., MD, PhD, Internal Clinic for Liver Disease Diagnosis and Treatment, Remedium s.r.o., teacher in St. Elizabeth University of Health and Social Sciences, Bratislava, Slovak Society of Practical Obesitology (SSPO), Bardejov. Interná ambulancia so zameraním na diagnostiku a liečbu chorôb pečene, Remedium s.r.o., 08631 Bardejovské Kúpele. mriab9@gmail.com, mbelovicova@kupele-bj.sk. 